\title{
Physico-chemical attributes of water of Hakaluki Haor, Sylhet, Bangladesh
}

\author{
Md. Tajul Islam*, M. Mahfuzur Rahman and Hassan Mahmud ${ }^{1}$ \\ Plant Ecology and Environment Laboratory, Department of Botany, \\ Jahangirnagar University, Savar, Dhaka-1342, Bangladesh
}

\begin{abstract}
Water quality assessment has been carried out in the Hakaluki Haor of greater Sylhet district during May, 2013 to February, 2014. Water samples were collected from 5 spots during 4 seasons and a total of 15 physico-chemical parameters were studied. Significant seasonal variation was observed in all seasons among physico-chemical parameters. $\mathrm{p}^{\mathrm{H}}$ values varied from 5.9 - 7.1, water temperature varied from $23.7-26.7^{\circ} \mathrm{C}$, transference varied from 23-53 $\mathrm{cm}$, TSS varied from 18.1-192 mg/l, TDS varied $25-193.5 \mathrm{mg} / \mathrm{l}$, EC varied from 30-680 $\mu \mathrm{s} / \mathrm{cm}$ , DO content of water varied from $4.6-5.6 \mathrm{mg} / \mathrm{l}$, BOD varied from 0.2-2.614 mg/l, COD varied from $38-312 \mathrm{mg} / \mathrm{l}, \mathrm{NO}_{3}-\mathrm{N}$ varied from 0.1-30.4 mg/l, $\mathrm{NH}_{3}$ varied from 0.9-2.18 mg/l, alkalinity varied from $12-42 \mathrm{mg} / \mathrm{l}$ and $\mathrm{PO}_{4}$ varied from $0.9-13.4(\mathrm{mg} / \mathrm{l})$. Agricultural and inorganic pollutants have been observed as the main causes of the Haor water pollution.
\end{abstract}

Key words: Physico-chemical attributes, Water, Hakaluki Haor, Sylhet.

\section{INTRODUCTION}

Wetlands play an important role in maintaining the ecological balance of ecosystems. Hakaluki Haor is located in the North-East of Bangladesh and belongs to two districts consisting of Moulvibazar ( $70 \%$ of the territory) and Sylhet (30\% of the territory) under Sylhet division. Hakaluki Haor is one of the Ecologically Critical Areas (ECA), which was once with plenty of aquatic resources including swamp forest. Macrophytes are the integral components of wetlands which are amongst the most productive ecosystems. Physico-chemical water parameters are among the factors, which determine the status of wetland ecosystem. Wetlands in Bangladesh have great ecological, economical, commercial and socio-economical values. They contain very rich components of biodiversity of national and regional significance. Water pollution is the contamination of water bodies (e.g. lakes, rivers, oceans, aquifers and ground water). Water pollution occurs when pollutants are directly or indirectly discharged into water bodies without adequate treatment to remove harmful compounds (Sharma \& Dubey, 2011). Water pollution affects plants and organisms living in these bodies of water. In almost all cases the effect is damaging not only to individual species and populations, but also to the natural biological communities. Water quality refers to the chemical, physical and biological characteristics of water. There are the measures of the conditions of water relative to the requirements of one or more biotic species and or to meet any human need

\footnotetext{
${ }^{1}$ Department of Environmental Sciences and Management, North-South University, Bangladesh *Corresponding author. Email: digitaltajuldu@gmail.com
} 
or purpose. These are the most frequently used as references (Jamie \& Richard,1996) to set standards against which compliance can be assessed. The most common standards used to assess water quality relate to health of ecosystems, human contact and drinking water. Water quality standards for surface waters vary significantly due to different environmental conditions, ecosystems, and intended human uses. The water quality parameters are determined by its intended use. Water quality depends on the local geology and ecosystem, as well as human uses such as sewage discharge, industrial pollution, use as collecting water and overuse. Contaminants that may be in untreated water include microorganisms such as viruses, protozoa and bacteria; inorganic contaminants, such as salts and metals; organic chemical contaminants discharge from chemical and petroleum industries use; pesticides, herbicides; and radioactive contaminants. Water quality of any wetlands is greatly changed by domestic sewage, herbicides, pesticides, insecticides, fertilizers, and industrial pollutants, which can seriously reduce the quality of river water and adversely affect aquatic life. The physical and chemical characteristics of water have strong influence on aquatic life. Fresh water has large and varied chemical contents. Innumerable materials enter the system from atmosphere, the catchments and its own basin. The chemical properties of fresh water not only alter the physical properties of the medium but also have significant bearing on the presence distribution and metabolic activities of aquatic organisms (Datta \& Datta, 1995). Physical and chemical water parameters are among the factors, which determine the status of wetland ecosystem; therefore considering increasing anthropogenic impact on Hakaluki Haor ecosystem, it is important to gather baseline data, which will allow to understanding the seasonal variations and changes the Physico-Chemical conditions of the wetlands.

\section{MATERIALS AND METHODS}

Sites selections were based on literatures reviews, consultation meeting of the experts in the related field and reconnaissance survey in the study area. Physical parameters have been studied at sites and chemical parameters were studied in the laboratory of the Department of Environment, GoB, Sylhet. Samples were collected from five locations of Hakaluki Haor as shown in Figure 1. Water samples were collected in four distinct seasons i.e. pre-monsoon (March-May), Monsoon (June-August), post monsoon (September-November) and winter seasons (December-February) from the selected spots. 15 vital parameters were selected for water quality analysis under two categories, viz. a) Physical parameters- pH, turbidity, Total Suspended Solid (TSS), Total Solid (TS) and Total Dissolved Solid (TDS) (APHA, 1971) b) Chemical parameters- Electrolitic Conductivity (EC), Dissolve Oxygen (DO), Biological Oxygen Demand (BOD), Chemical Oxygen Demand (COD), $\mathrm{NO}_{3}-\mathrm{N}, \mathrm{NH}_{4}-\mathrm{N}$, Alkalinity, Phosphate (APHA, 1971). Study area and selected sites have been shown in maps (Fig. 1). 


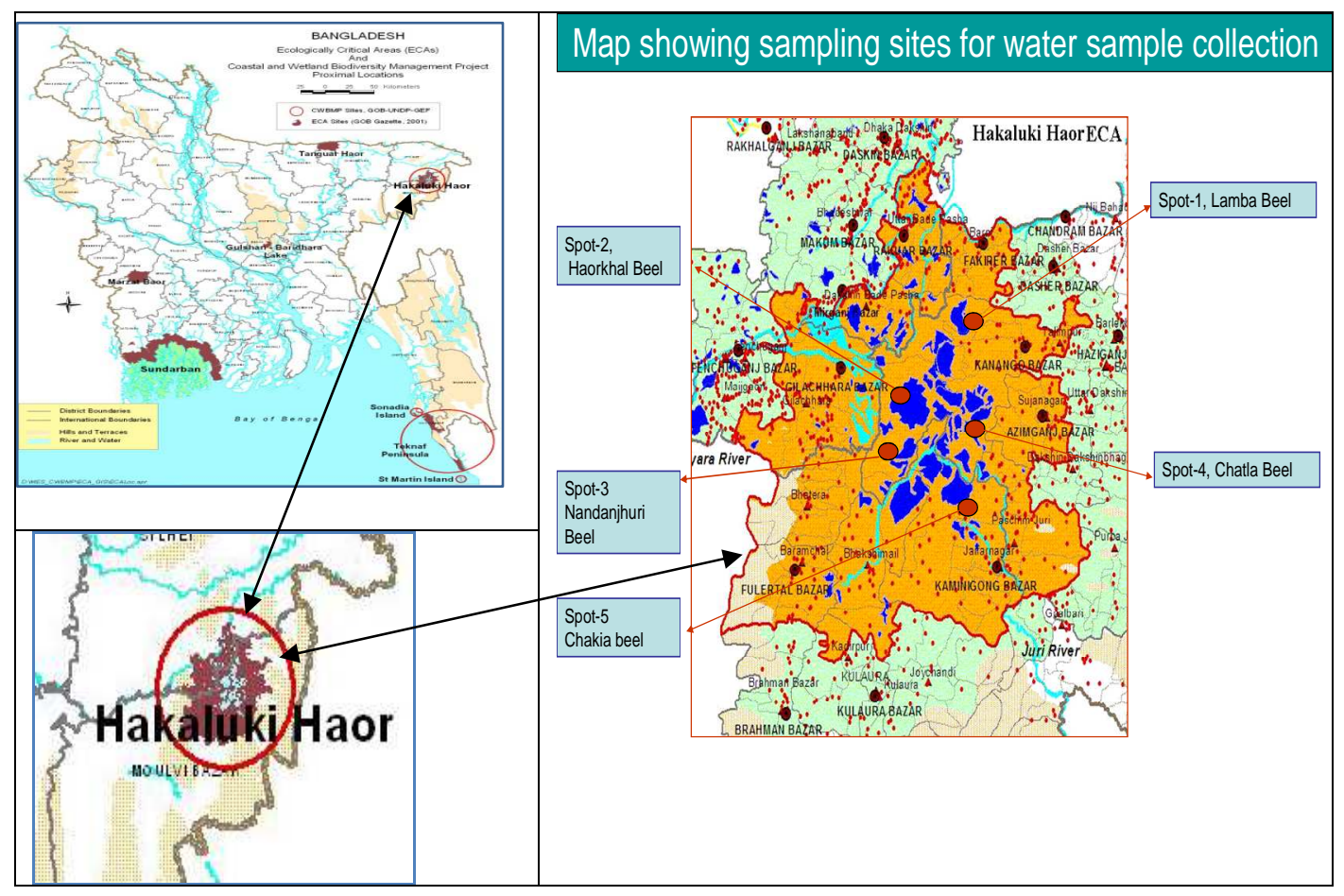

Fig. 1. Map showing Hakaluki Haor and selected study sites

Proper sampling procedures were followed carefully to inhibit the intrusion of any foreign particles that may affect the results. Rests of the samples were analyzed in laboratory. Physical parameters studied as described below: $\mathrm{pH}$ were measured by $\mathrm{pH}$ meter, water temperature were measured by centigrade thermometer, transparency by Sacchi disc, water color by visual method, water depth by meter scale, TSS, TDS and TS by gravimetric method (Goutom, 1990), while EC by Hanna model 8033, DO by (Hanna, model, H19143).

Estimation of the chemical variables which include, BOD by Winkler`s method De (1996) and Sawyer et al. (2002), COD by Trimetric method De (1996) and Sawyer et al. (2002), Nitrate- Nitrogen by Colorimetric method (1996) and Sawyer et al. (2002), Ammonia by Microkjeldahl distillation method (1996) and Sawyer et al.( 2002), Phosphate by Blue color method and Alkalinity by Titrimetric method (1996) and Sawyer et al. (2002). Micro-kjeldhal distillation method as described by Jackson (1962) and titrimetric method as described by Vogel et al. (1989) respectively. 


\section{RESULTS AND DISCUSSION}

Physico-chemical data of the present study have been presented in Table 1. Water quality of Hakaluki Haor decline gradually due to anthropogenic pressure and human interventions. Most aquatic animals prefer $\mathrm{pH}$ range of $6.5-8.0$. Outside of this range (6.5 to 8$)$ the diversity in the haor reduces because it stresses the physiological systems of most aquatic organisms and can reduce reproduction. In Post-monsoon the average highest $\mathrm{pH}$ was 6.66 and in winter the lowest $\mathrm{p}^{\mathrm{H}}$ was 6.22. The Hydrogen ion concentration $(\mathrm{pH})$ is an important factor as measure of water quality. The waste water can alter the $\mathrm{pH}$ of natural water (Motwari et al. (1956). Trevedi \& Raj (1992) reported that 6.8 to 9.0 as the optimum $\mathrm{pH}$ range for the aquatic life in water bodies. Higher turbidity increases the water temperature because suspended particles absorb more heat or sunlight, in turn reduced DO because of warm water holds less DO. The DO content of natural water varies with the temperature, photosynthetic activities and respiration or decomposition of plants and animals (Cunningham \& Siago, 1995). According to Lagler (1972) DO content less than $3 \mathrm{mg} / \mathrm{l}$ is harmful to fishes. High turbidity levels can reduce the amount of light reaching lower depths, which can inhibit growth of plants depends on them. Turbidity diffuses sunlight and slows photosynthesis. Plants begin to die and increasing BOD reducing the amount of DO and increasing the acidity. Highest turbidity observed in the pre-monsoon and winter and lowest in monsoon. Dissolve Oxygen did not cross the standard value, STV=4.5-8 mg/l, (ECR, 1997), which is normal for aquatic organism and for macrophytes. Highest DO observed in the monsoon because of water comes from upstream and lowest in winter. Dissolved oxygen below $5.0 \mathrm{mg} / \mathrm{L}$ stresses aquatic life, below 1-2 mg/L can result in massive fish kills. $\mathrm{BOD}_{5}$ is harmful to aquatic flora and fauna like fish and microorganisms (Kabir et al., 2002). Oxygen levels also can be reduced through over fertilization of water bodies by runoff from fields containing phosphate and nitrates. Under these conditions the number and size of aquatic plants increase. If weather becomes cloudy for several days, plants use more oxygen for respiration. In some spots EC value was higher than that of standard value which affects the aquatic flora. In the post monsoon EC value of all spots cross the standard value, which is harmful for aquatic lives of the Haor.

Total Suspended Solids below $20 \mathrm{mg} / \mathrm{L}$ is considered to be clear; between $40-80 \mathrm{mg} / \mathrm{L}$ appears cloudy; above $150 \mathrm{mg} / \mathrm{L}$ is considered to be dirty. Water was cloudy in the post monsoon. Highest TSS observed in the post monsoon and lowest in the winter. TSS varied from 18.1-192 $\mathrm{mg} / \mathrm{l}$, which in some spots crossed the standard value (STD=150 $\mathrm{mg} / \mathrm{l})$, which is harmful for aquatic organism. TDS varied from 18.2-159.5 mg/l, $(\mathrm{STD}=150 \mathrm{mg} / \mathrm{l})$.The values higher than standard values would affect the aquatic flora. Highest TDS observed in the Post- monsoon and lowest in the monsoon. It crossed the standard value during post monsoon which would create stress on the aquatic life.

BOD varied from $0.2-2.614 \mathrm{mg} / \mathrm{l}$, which crossed the standard values (STV=0.2 $\mathrm{mg} / \mathrm{l}$, ECR, 1997). BOD is one of the most common measures of organic loading in water. Low BOD means good water quality and high BOD means polluted water. Highest BOD observed in monsoon and lowest in winter. Highest COD observed in post-monsoon and lowest in monsoon. Typically, unpolluted surface water has BOD values of $2 \mathrm{mg} / \mathrm{l}$ or less. 
Nitrate recommended below $10 \mathrm{mg} / \mathrm{l}$ for drinking water and below $0.5 \mathrm{mg} / \mathrm{l}$ for aquatic life. The test showed very high concentration of $\mathrm{NO}_{3}-\mathrm{N}$ in some spots. Alkalinity was more or less uniform in most of the parts of the present study area. Comparatively highest alkalinity observed in the season of winter followed by post-monsoon and winter and lowest was in pre-monsoon. The values for Ammonia ranged between $0.43 \mathrm{mg} / \mathrm{l}$ (winter season) and $1.58 \mathrm{mg} / \mathrm{l}$ (Pre-monsoon).The permissible limit of which according to Bangladesh Standard (BDS, 1975) is $0.5 \mathrm{mg} / \mathrm{l}$. Thus ammonium ions in the water of Hakaluki Haor are unsafe for drinking. This can be as a result of human and animal wastes disposal, as well as fertilizers loading. Besides agricultural practices in the khanda of beels and tea garden surrounding Hakaluki Haor and during flash flood water come from upstream with polluted water. Most of the spots have been polluted in all seasons by ammonia without some exception. Phosphate contents were found higher than standard value (STV=6mg/l, Ref. ECR, 1997) probably due to the establishment of 'bathan' (cattle grazing area) during winter inside the haor area, which produces animal and human wastes. Another source is the use of fertilizers in the paddy fields.

Large amount of agrochemical have been used in the paddy field, poisons have been used for fishing after dewatering the beels and chemical have used surrounding tea garden of Hakaluki Haor. These chemicals polluted the water of Hakaluki Haor and ammonia and or nitrate have increased on alarming scale and have polluted the water of Hakaluki Haor. Water qualities of Hakaluki Haor in different seasons have been presented in Table 1.

Table 1. Maximum and minimum values of the physico-chemical properties of water samples of Hakaluki Haor at Sylhet, Bangladesh

\begin{tabular}{|c|c|c|c|c|c|c|c|c|c|c|c|c|c|}
\hline \multirow[t]{2}{*}{ Variables } & \multicolumn{3}{|c|}{$\begin{array}{c}\text { Pre-monsoon (Mar- } \\
\text { May) } \\
\text { 2013-2014 }\end{array}$} & \multicolumn{3}{|c|}{$\begin{array}{l}\text { Monsoon (Jun- } \\
\text { Sep.) 2013-2014 }\end{array}$} & \multicolumn{3}{|c|}{$\begin{array}{l}\text { Post - Monsoon } \\
\text { (Oct-Nov.) 2013- } \\
2014\end{array}$} & \multicolumn{3}{|c|}{$\begin{array}{l}\text { Winter(Dec.-Jan.) } \\
\text { 2013-2014 }\end{array}$} & \multirow[t]{2}{*}{$\begin{array}{l}\text { Standa } \\
\text { rd } \\
\text { value, }\end{array}$} \\
\hline & Min. & Max. & Avg. & Min. & Max. & Avg. & Min. & Max. & Avg. & Min & Max. & Avg. & \\
\hline $\mathrm{pH}$ & 6 & 6.8 & 6.38 & 6 & 7.1 & 6.56 & 6.3 & 7 & 6.6 & 5.9 & 6.6 & 6.22 & $6.5-8.5$ \\
\hline Turbidity $(\mathrm{cm}$ & 48.0 & 56.0 & 51.0 & 30.0 & 34.0 & 32.6 & 36.0 & 40.0 & 38.0 & 48.3 & 53.3 & 50.0 & 0 \\
\hline Temp. $\left({ }^{\circ} \mathrm{C}\right)$ & 27.0 & 26.7 & 26.6 & 27.0 & 28.0 & 27.6 & 24.0 & 24.0 & 23.9 & 26.2 & 26.2 & 26.2 & $20-300 \mathrm{C}$ \\
\hline $\mathrm{DO}(\mathrm{mg} / \mathrm{L})$ & 4.5 & 4.68 & 4.6 & 5.0 & 5.6 & 5.26 & 4.6 & 5.5 & 5.04 & 4.5 & 5.0 & 4.7 & $4.5-8$ \\
\hline $\mathrm{EC}(\mu \mathrm{S} / \mathrm{cm})$ & 68.0 & 125 & 92.1 & 36 & 91.0 & 61.3 & 63.0 & 589.0 & 204 & 91.7 & 324 & 207.4 & 1200 \\
\hline TSS(mg/L) & 105 & 193.5 & 142.22 & 25.41 & 63.77 & 43.03 & 92.1 & 292.0 & 151.66 & 45.8 & 175.2 & 106.5 & 2100 \\
\hline TDS(mg/L) & 33.24 & 105.7 & 65.67 & 18.2 & 45.6 & 30.74 & 53.17 & 320.2 & 136.85 & 18.1 & 64.6 & 41.44 & 150 \\
\hline $\mathrm{TS}(\mathrm{mg} / \mathrm{l})$ & 47.76 & 137.66 & 76.55 & 7.21 & 18.17 & 12.29 & 27.0 & 132.37 & 65.824 & 27.7 & 110.6 & 65.05 & 2250 \\
\hline $\mathrm{COD}(\mathrm{mg} / \mathrm{L})$ & 36.0 & 133 & 83.4 & 38.0 & 76.0 & 53.8 & 51.0 & 408.0 & 187 & 45 & 312 & 164.8 & 200 \\
\hline $\mathrm{BOD}(\mathrm{mg} / \mathrm{L})$ & 0.3 & 0.86 & 0.62 & 1.0 & 2.6 & 1.88 & 0.2 & 1.3 & 0.7 & 0.2 & 1.0 & 0.57 & 0.2 \\
\hline $\begin{array}{l}\text { Alkalinity } \\
(\mathrm{mg} / \mathrm{L})\end{array}$ & 12.0 & 42 & 26.4 & 12.0 & 28.0 & 18.4 & 12.0 & 30.0 & 23.2 & 18 & 30.0 & 23.2 & $200-500$ \\
\hline $\begin{array}{l}\text { NO3-N } \\
(\mathrm{mg} / \mathrm{L})\end{array}$ & 5.6 & 29.7 & 15.6 & 1.0 & 30.0 & 7.54 & 0 & 2.2 & 0.88 & 0.1 & 2.3 & 0.86 & 10.0 \\
\hline NH3(mg/L) & 1.2 & 2.18 & 1.58 & 0 & 1.1 & 0.55 & 0.1 & 1.5 & 0.56 & 0.07 & 1.1 & 0.434 & 0.5 \\
\hline PO4 (mg/L) & 3.7 & 7.9 & 5.58 & 1.0 & 7.5 & 3.5 & 5.6 & 13.0 & 8.24 & 5.4 & 12.2 & 7.58 & 6.0 \\
\hline
\end{tabular}

Legend: Min. = Minimum; Max. $=$ Maximum; Avg. = Average 
Acknowledgement: First author is thankful to the Ministry of Science and Technology, Government of Bangladesh for awarding 'Banghabandhu Fellowship on Science and ICT Project'.

\section{REFERENCES}

APHA.1971. Standard Methods for the Examination of Water and Waste Water. American Public Health Association, New York, USA. 591(602).

BDS, 1975: The Bangladesh Development Studies. 3(4): 403-423.

BECA, 1995. The Bangladesh Environment Conservation Act (BECA) has provision for Ecologically Critical Area (ECA): 1-11.

Cunningham, W. P., Siago, B. W. (1995) Environmental science. A global concern press $3^{\text {rd }}$ edition, WHC Brown publisher.

Datta, J and Datta, J. S. 1995. Fundamentals of fresh water Biology. Narendra Publishing House, Delhi-110006, India. 5-31.

De. A. K. 1996. Environmental Chemistry, New Age International P. Limited, India. 268-269.

ECR, 1997. The Environment Conservation Rules 1997, Government of the People`s Republic of Bangladesh, Ministry of Environment and Forest. 179-227.

Goutom, A. 1990. Ecology and Pollution of Mountain water (A case study of Bhagirathi River). Ashish Pub. House, New Delhi. 23-27.

Jackson, M. L. 1962 Soil Chemistry Analysis, Constable and Ltd. 47-88.

Jamie. B. and Richard, B. 1996. Water Quality Monitoring - A Practical Guide to the Design and Implementation of Freshwater Quality Studies and Monitoring Programmes Published on behalf of UNEP/WHO. 1-348

Kabir, S. E. Kabir, M. Mia. C.M. Begum, N. Chowdhury, D. Sultana, M. S and Rahman, M. S. 2002. Assessment of effluent quality of Dhaka Export Processing Zone with Special Emphasis to that of the Textile and Dyeing Industries: Jahangirnagar University Journal of Science, 25:137-14.

Lagler, K .F. 1972. Fresh water Biology.2nd Edition, .W. M. C Brown Company, Publisher, Dupuque, IOWA, $421 \mathrm{pp}$

Motwari. M. P. Banejera, S and Karmachandani, S. J. et al (1956). Some observation of the river gone be factory effluent of the Rothas Industries and Dalminagar (Biher).

Sawyer, C. Mc. Carty, P. and Parkin, G. 2002. Chemistry for Environmental Engineering and Science, Mc Graw-Hill Co. 768.

Sharma, D. and Dubey, A. 2011. Seasonal Study of Nutritional Status for Microcystis Aeruginosa and Water Hyacianth of Water bodies of Indore, India. Annals of Biological Research .2011. 2(3):461-468.

Trevedi, P. R. and G. Raj, 1992. Water Pollution. Pub. By Akashdeep pub. House, New Delhi, India 304 PP.

Vogel, J. S., Briskin, M., Nelson, D. E. and Southon, J. R. 1989. Ultra-small carbon samples and the dating of sediments. In Long, A. and Kra, R. S., eds., Proceedings of the 13th International ${ }^{14} \mathrm{C}$ Conference. Radio- carbon 31(3): page: 601-609. 